\title{
CRITERIA OF SUSTAINABLE RECONSTRUCTION AND ACCEPTANCE OF THE HISTORIC TOWN SQUARES IN SERBIA
}

\author{
A B S S T R A C
}

The common feature of contemporary approaches to urban reconstruction is sustainability. For a number of years now, there has been considerable research on the ecological, social and economic aspect of sustainability. In addition to these three pillars, the document Rio+20 introduced the crucial role of culture into the establishment and execution of the paradigm of sustainability. Sustainable tourism, cultural and creative industries and urban revitalization of heritage are the key economy sectors that generate successful local development and strengthen creativity. Public spaces, seen through the prism of sustainability, is the public and cultural capital citizens use, transform, enlarge and then transfer on to future generations. With this in mind, the reconstruction and improvement of the historic town squares as representative public space has particular importance, made yet more significant in our country, given that the regulation of first squares in Serbian towns in 19th and 20th century has been the result of state aspiration towards the European cultural milieu and its endeavor to determine national identity within the framework of European values. 
RECONSTRUCTION OF THE HISTORIC TOWN SQUARE IN SERBIA AND SUSTAINABLE STRATEGIES

Town squares built in Serbia in the $19^{\text {th }}$ and $20^{\text {th }}$ century, following examples of European squares, represents a significant urban endeavor, as well as a trace of the attempt to emulate the European model of social and spatial relations. ${ }^{1}$ This work does not analyze particular cultural monuments or architectural heritage that form the historic town square, but rather the space of the square and the city matrix as valuable cultural and vernacular heritage. This term has a number of overlapping definitions, but we consider cultural heritage as the all the various cultural and creative expressions, from the natural, the built (archeological sites, monuments, historical towns and units), art pieces, historical cities, literary, music, audiovisual works, even including knowledge, practices and traditions. ${ }^{2}$

This portion of the text points to the significance of the planned town matrices and squares for an integral development of historic towns central zones. We can see that their importance is the result of the wish to use the European model of urban development - in the founding of towns, as well as in their rehabilitation today - to drive Serbia to be recognized as part of the European cultural space. ${ }^{3}$

The Future We Want, the declaration RIO+20 adopted in 2012, ${ }^{4}$ indicates the topics and areas of activity insufficiently considered in previous documents and global partnerships, and which would demand additional attention in the period after 2015 for the execution of goals and principles of overall sustainable development. The importance of developing inter-sector topics was underscored in that they simultaneously contribute to key dimensions of sustainable development: the economy, society and living environment. Sustainable cities and human settlements and sustainable tourism were recognized as the main topics of the theme of integral development of space and settlements.

In discussing the theme Sustainable Cities and Human Settlements ${ }^{5}$, the declaration indicates the significance of the protection of natural and cultural heritage, the revitalization of historical districts and the rehabilitation of town centers. Further, it strongly emphasizes the commitment to an integral approach in planning and executing sustainable towns and settlements. Particular importance is paid to support given to local governments, with the aim of raising awareness in the public and strengthening the participation of all citizens, in order for the endeavor to be adequately developed and implemented.

According to the Leipzig Charter on Sustainable European Cities (2007) ${ }^{6}$, the given approach is favored as the precondition for a successfully sustainable city. The importance of the Leipzig Charter is in that Europe is turning towards 
the city as the bearer of the strategy of the development of the region. With its engagement in this field, Serbia has included itself among the group of countries that conduct integral urban development of (parts of) cities on the local level. With the help of international organizations and European Union funds, along with the support of the designated ministry of the Republic of Serbia, and as part of its project Strengthening of Local Land Management in Serbia, Module 1: Urban Land Management, ${ }^{7}$ the organization GIZ proposed strategies of integral urban development of the central town zone of three regional centers: 1) Užice - center of the Zlatibor region; 2) Kraljevo - center of the Raška region; and 3) Kragujevac - center of the Šumadija region.

The proposed strategies provide goals by sector and executive measures, with the following inter-sectorial themes: 1) accessibility; 2) quality of living environment and sustainability; and 3) participation of citizens. The theme of participation of citizens is all the more important given the problem of acceptance of space of the historic town square, and we further consider this link in the following chapter of this text. The aims of the strategies are based on local resources of the city and region and divided, by temporal criteria, into: short-term (realized in the next five years), mid-term (realized in ten years) and long-term (realized in ten to fifteen years). Specific development goals are derived from general goals, with thematic or spatial specificities ${ }^{8}$, and the subject of reconstruction of town squares is in the area of urban structure and public space development, and falls under short-term goals (to be realized in the first five years). The spatial reach of these strategies is the central city zone, in which the square has a specifically considered role, given its significance and influence on the development of space and settlement.

The Square of Partisans in Užice falls under the area of intervention No.2, "City Core," and is documented under spatial cultural-historical unit of particular aesthetic, architectural and urban significance for the historic town as a whole. The document lists measures that contribute to the valorization and revitalization of Square of Partisans, including the urban and technical analysis and documentation for its reconstruction, devised by way of participatory approach, based on the results of the urban project competition ${ }^{9}$.

This square in Kraljevo is the epicenter of the historic town matrix, and the strategy recognizes that it is essential it be preserved ${ }^{10}$. The sustainable development of the town is based on a strong cultural identity of the town. As part of the cultural heritage, the document defines goals and priority projects, in particular the revitalization of Kraljevo's old city core (reactivation of back of the main street) and expansion of festival activities. ${ }^{11}$ 

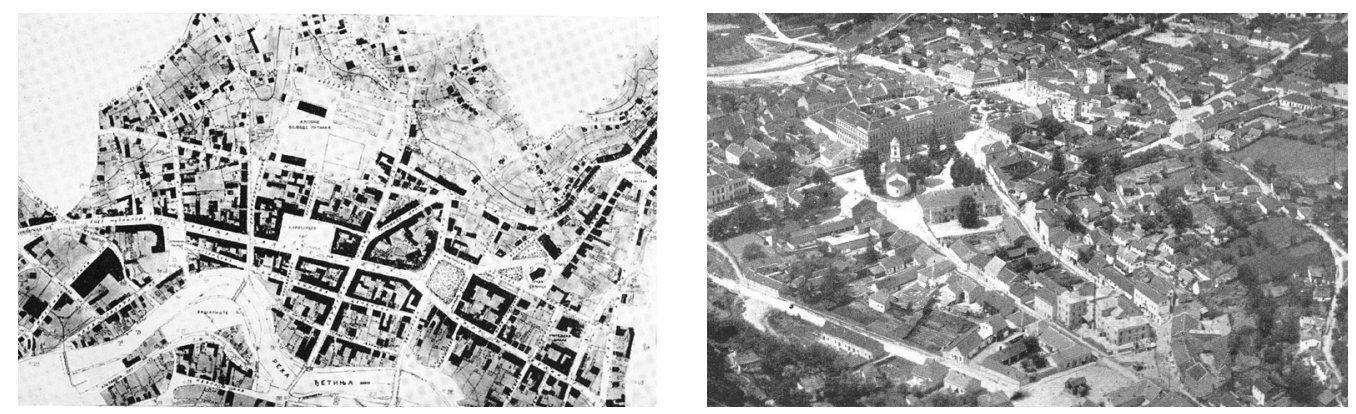

Figure 1. Užice, the town plan and the old photograph from 1930s (B.Maksimović, fig. 93, p.123; fig. 26, p. 39)
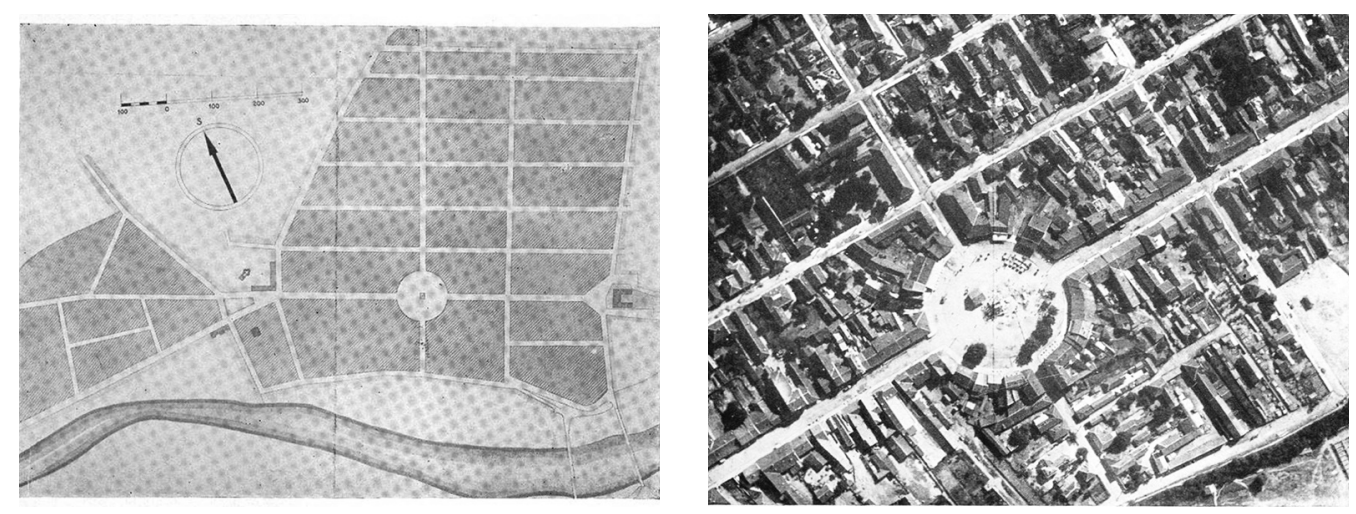

Figure 2. Kraljevo (Karanovac), the town plan and the photograph of the square from 1930s (B. Maksimović, fig. 80, p.108; fig. 94, p. 124.)

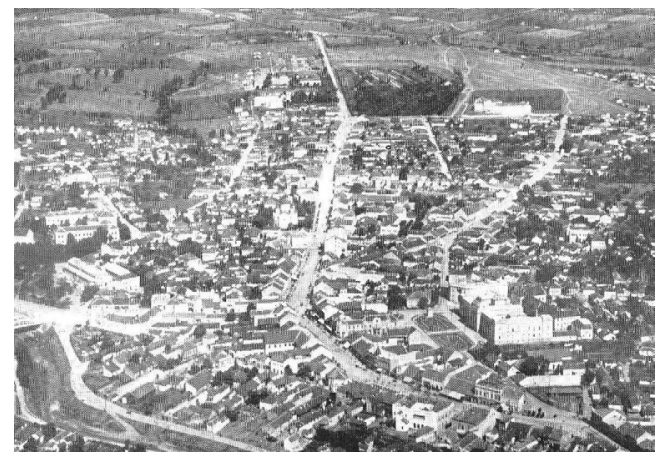

Figure 3. Kragujevac, the town plan and the old photograph from 1930s (B. Maksimović, fig. 27, p. 39) 

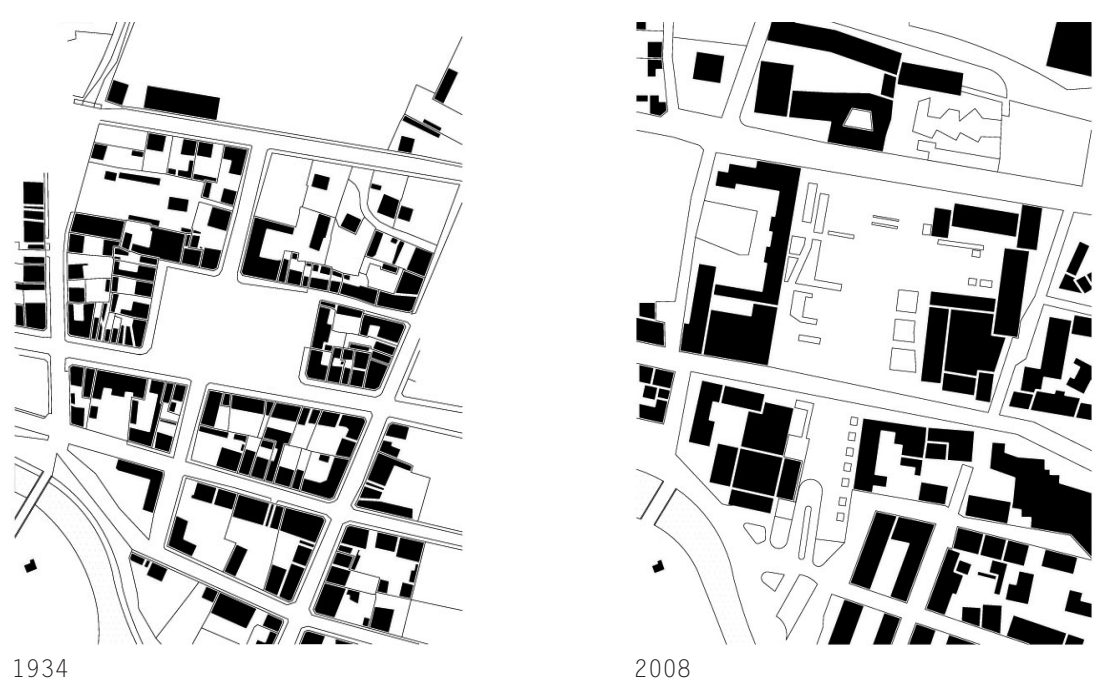

2008

Figure 4. Užice town square transformation (V. Djokić, p.214, p.215)
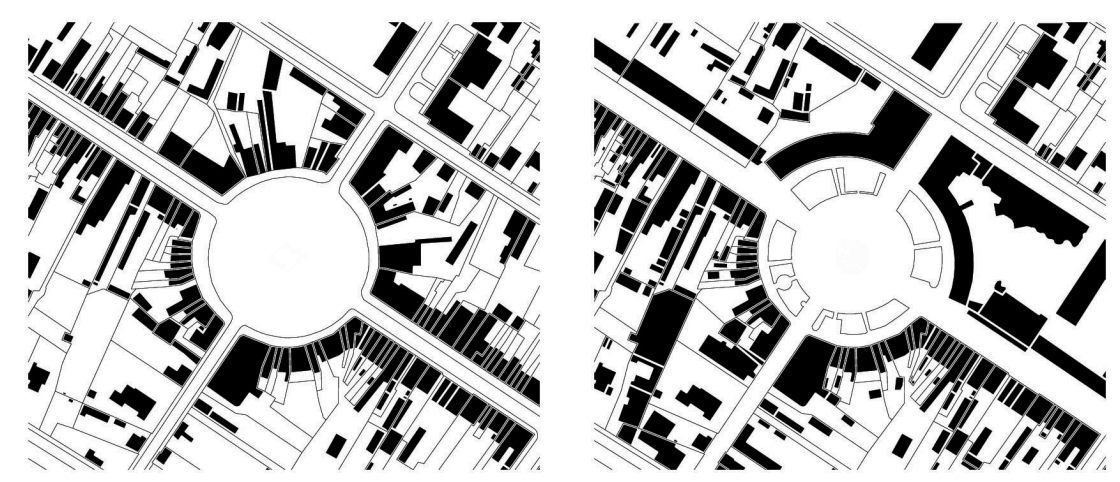

1948

Figure 5. Kraljevo town square transformation (V. Djokić, p.142, p.143)

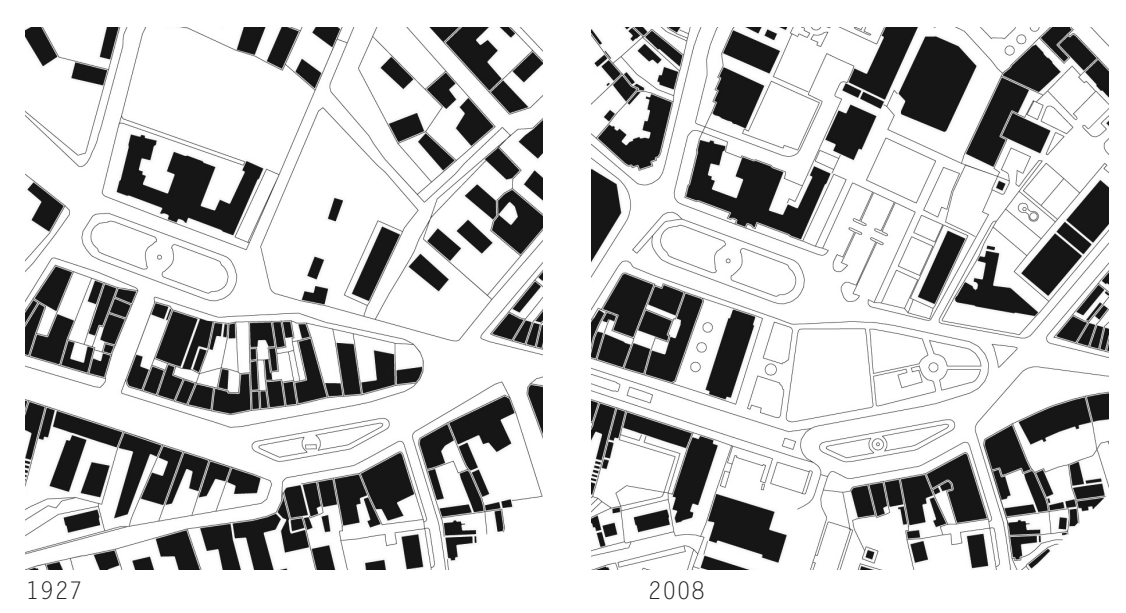

Figure 6. Kragujevac town square transformation (V. Djokić, p.364, p.365) 
The old square in Kragujevac is located in an area that merges and gives form to public spaces. It makes better use of spatial features and is more densely occupied by traditional houses whit shops and dwellings. ${ }^{12}$ Particularly important for the development of the historic town are the brownfield locations, of special cultural heritage from the period of industrialization, while the existing public spaces (including the main town square) play a role in the formation of the pedestrian zone in the heart of the city, as well as increasing the comfort and enjoyment of public spaces ${ }^{13}$. As a public good, cultural monuments become public spaces that produce social as well as economic and ecological capital. Cities and regions that hold these monuments become initiators of economic activity, centers of learning, epicenters of creativity and culture, places of interaction within a community and actors of social integration. The development of public spaces influences the creation of innovation and contributes to sustainable and integral growth of settlements and towns, in accordance with the goals of the EU 2020 strategy. ${ }^{14}$

The strategy of integrated urban development for these cities refers to the historic central town zone and is based on the values of the region of which they are the hub. The strategies particularly define the relation of the city and the region, presented and elaborated in the section Industry and Tourism.

Sustainable tourism, if it is thought through and well organized, can prompt new jobs and trade. Developing in support of this branch of the economy are also activities and programs to raise awareness of the living environment, its conservational or protection needs, while respecting and promoting ecosystems, biodiversity and cultural diversity as encountered. Special consideration is given to the application of principles of sustainability in developing countries while emphasizing the role of sustainable tourism that strongly encourages investment in the given region. Increasing the quality of living conditions of local communities and support to the local economy and environment can lead to more favorable results in realizing goals of sustainable development.

Ecotourism and cultural tourism as forms of sustainable tourism are eligible for financial and logistical support from the United Nations in promoting regulation that would legally enable its initiation and execution. The European Union supports sustainable tourism through the activities of its $\mathrm{OMC}^{15}$ group for the year 2017-2018. ${ }^{16}$ Other international organizations recognize sustainable tourism, culture and creative industries, urban revitalization of heritage as powerful sectors of the economy that generate self-employment, stimulate local development and strengthen creativity, and thus see in them the key factors for the development and execution of the concept of sustainability. ${ }^{17}$ 
Due to their size, character, purpose and epicenter position in the historic central zone, the squares in these towns have a significant role in the promotion of attractive destinations in the region. Užice is the hub of the Zlatibor region, drawing on Zlatibor's existing attractions as a real basis for the development of tourism. The strategy suggests building and expanding the network of tourist locations and organizing events and manifestations, as well as supplementing existing transit tourism with the development of event tourism. Kraljevo is a town that has a strong connection with historical and cultural heritage of medieval and modern Serbia, given that the monastery Žiča is on the outskirts of the town, and the very center of the town has been formed on an orthogonal matrix with a round city square in its center, a feature recognized as extraordinary urban heritage from the period of city-founding. ${ }^{18}$ Kragujevac bases its development on cultural identity and the desire to recapture the strength of the industrial town through projects of transformation of large factory and military complexes, and the building and the important industrial heritage of modern Serbia. ${ }^{19}$

Both the tangible and intangible European cultural heritage is the public good and a common resource, that is, the heritage of previous generations for future generations of Europeans. ${ }^{20}$ For the European Union this is a unique treasure of knowledge and a valuable resource of economic growth, employment and social cohesion. Much like other resources, cultural heritage can be endangered by overexploitation and insufficient financing, leading to neglect, deterioration and oversight. As the European cultural heritage is a common resource, its care (the reconstruction, sanitation, maintenance) is a common responsibility. The preservation of the cultural heritage is above all a matter of national, regional and local government, while the European Union's role is in accordance with EU agreements and regards principles of subsidiarity. The relation to European cultural heritage (how it is valued and preserved) is the main factor in Europe's recognition in the world as a desirable place for life, work and visit.

The indicated cities in Serbia have gone through the methodological process of development and adoption of strategies of integrated urban development, according to which they have adopted the contemporary model of urban development and enabled their own access to sources of financing of urban development from the Republic of Serbia and the European Union ${ }^{21}$. In the ensuing chapters, we will elaborate the role of participation and sustainable urban design in relation to the problem of acceptability of the historic town square. 


\section{PLANNING AND THE QUESTION OF ACCEPTABILITY OF THE HISTORIC TOWN SQUARE}

Vladan Djokić documented both the oversights made and the necessary directions for the reconstruction of Serbian city squares based on typo-morphological research of thirty squares ${ }^{22}$. One of the more significant determinants of a city square in Serbia is the low level of acceptance of the square. This weakness is explained by an absence of continuity in development of resident consciousness and culture.

The absence of continuity in the development of resident culture is further explained by Vladimir Macura: "The muddy and mucky square spreading before important state and civic buildings could not satisfy the mentality of bourgeois society that historically, perforce was unable to have either a city or bourgeois culture, but nevertheless yearned strongly for both." ${ }^{23}$ Nikola Dobrović criticizes the bourgeois mentality and an absence of any need for honest productivity, which for him represented the main reason why the reconstruction and modernization of Serbia had abundant, but low quality, building ${ }^{24}$. These thinkers explain the problem of acceptance through a specific cultural identity formed by the influence of Turkish customs and understanding of public space, public life and city culture ${ }^{25}$.

The acceptance of the town square is scarcely covered in studies of public spaces in Serbia, meaning that there are no clearly defined samples why a square is not used in accordance with the goals defined in the initial project. Sustainable reconstruction of the historic town square would assume adequate governance of such samples throughout the life cycle of the project, in order for the causes to be removed and their influence mitigated, creating the greatest possible acceptance of space. The questions before us are what are the criteria that would represent the problem of acceptance of space and what kind of approach to take in the process of reconstruction of the city square that would result in the greatest possible acceptance. Acceptance is a neglected goal of reconstruction, meaning that the result of reconstruction is not only an aesthetically valuable space or new pavement and better square features, but a public space used and maintained according to its size, position and significance it carries in the city matrix. The achievement of the greatest possible acceptance of the town square ought to be the basic goal of the project of reconstruction, so obviously neglected. 
We define the factors that impact the acceptance of square space through the risks that could appear over the course of the execution of the project of reconstruction. Risk is an uncertain event or state that, should it arise, has a positive or negative influence on the aims of the project, and risk management is one of the most important processes of managing projects and one that directly influences the overall success of the project. Risks exist in all phases of the project, and specific risks can appear in more than one phase.

There are any number of areas in which risks could potentially occur. One of which is certainly the Program of Urban Development, which runs the risk of participation: either a threat in the execution of a project (inadequate participation) or an opportunity for the participation of citizens, the local community and stakeholders to adequately influence the program of urban development and acceptance of the space of the square (adequate participation). Looking at the field of Program of Urban Development, in addition to participation, there are a number of risks (causes), which, in taking place, could have a direct or indirect negative impact on the acceptability of the space of the square: inadequate analysis of the existing state and needs, limiting plan/ technical documentation, poorly executed urban or architectural competition, an ad hoc project in the service of a political campaign, as well as many others that depend on the specific project.

\section{PRINCIPLES OF SUSTAINABILITY IN THE URBAN DESIGN OF PUBLIC SPACE}

Sustainable urban design conducts a systematic and synergic reorganization of the living environment, the economic and socio-economic aims that represent a long-term advancement of the health of the natural environment and the vitality of urban communities ${ }^{26}$. The following questions are important for us in this text: What principles of sustainability are being advocated and executed in the design of public space such as the city square? What kind of square design ensures its success? Which process of urban design of the city square ensures a higher level of its acceptance in Serbia?

Numerous authors and teams of researchers offer suggestions for the organization of city space in accordance with principles of sustainability. Researching which principles lead to a balanced development of all three aspects (social, economic and natural environment) results in principles of sustainable development. Architects, urban scientists and other members of the team that run the project of reconstruction of the city square, build these principles into the process of project execution, which is how sustainable urban development emerges. 
Without sustainable procedures and an understanding of urban design as a process (and not simply a spatial solution), sustainable urban design cannot be achieved. Efforts and studies thus far have not yielded any general principles of sustainable urban design, but have rather, for each specific case, respecting local context, established adequate principles and criteria.

What all the approaches to sustainable urban design have in common is a comment given by Frey, that there is an inter-relationship among the social, the physical and specificities of city structure and its qualities. The research of said relations ought to advance the comfort of lived environment ${ }^{27}$.

In an attempt to found an integrative theory of urban design, Sternberg unifies the approaches of key theorists and critics of city shaping and planning (Sitte, Lynch, Jacobs, Norbert-Schulz). In so doing, he offers the following criteria for city space: good form, readability, vitality, meaning, to which he adds comfort as a fifth integrative dimension of the experience of urban space ${ }^{28}$.

Apart from the inescapable theme of sustainable city, Jan Gehl reminds us of the human scale, the pedestrian perspective and sensibility sought and expressed by people in public spaces. In Cities for People, he describes the importance of public space for the interaction of citizens ${ }^{29}$. A city that allows for the possibility of basic human activities of people - seeing, hearing, speaking - is a good city for meeting. To this end, he particularly emphasizes squares and pedestrian zones that allow for exchange of stories, positions, ideas and talents of varying intensities: from quiet conversations to thunderous protests. In order to encourage the sociability of people, there should be events in squares and pedestrian zones that attract people precisely for these elementary social needs: to see others and be seen, to hear and converse (in soft tones to remarkable political speeches). Good urban design ought to ensure comfortable surfaces for walking, standing, sitting. Acoustic spaces for street art and places where people can express their talents, an atmosphere of pleasant relaxation and enjoyment of city life and times. Gehl offers an argument that favors the pedestrian and bike traffic against vehicular, that is, the removal of vehicular traffic in portions of central city zones, in order to provide better circumstances for conversation and enjoyment of the city environment (to be able to hear sounds otherwise inaudible due to traffic). Although the paradigm of sustainability also develops awareness of limited resources and human responsibility for climate change, Gehl's approach is above all humanist: he thinks that design of public spaces ought to contribute to a good life in the city, which is not measured by high standard of living in closed communities, but by available features and experiences of the city life in public space. 
As a tool for urban designers, Gehl offers twelve criteria of good public space. They are broken down into three categories: protection, comfort and enjoyment. ${ }^{30}$ For each of the three categories, he offers detailed criteria. The feeling of protection means the security from traffic and other accidents, from crime and violence, from inclement weather. Whether the design has ensured comfort is confirmed based on six criteria: the possibility of walking, lingering, loitering, of sitting, seeing, conversing and hearing, of playing and exercising. Enjoyment or pleasure is achieved by the human scale dimension of space, the possibility of enjoying the pleasant weather conditions, and finally, to experience positive sensory feelings (a beautiful view, tactile experience of applied materials, the sound and freshness of water, the scent and color palette of greenery).

Based on a study of over a hundred city squares the world over, the organization Project for Public Spaces selected ten principles characteristic for a successful realization of city squares. Any successful city square is characterized by: 1) image and identity; 2) a number of attractions and destinations; 3) amenities; 4) flexible design; 5) seasonal strategy; 6) access; 7) inner square and outer square; 8) reaching out like an octopus; 9) central role of management; and 10) diverse funding sources. ${ }^{31}$ We bring these principles for the successful execution of projects of city squares in contact with the question of acceptance and look at the ones most relevant for examining risk that impacts acceptance of city square space in Serbia.

1. IDENTITY. Throughout history, city squares have been centers of communities and they were instrumental for the formation of the identity of the city as a whole. This connection with tradition and culture that is felt even today in weathered city squares confirms the role of the square in the cultivation of feeling of belonging to a culture and a city. Previously this significance was established and confirmed by way of construction of important institutions (administrative buildings, churches, judicial buildings, cultural monuments) and placing exceptional artistic achievements that become city icons (monuments, fountains, drinking fountains, contemporary artistic installations). The challenge in contemporary society has been the return of feeling of belonging to the community/city, creating the need for innovative solutions, that is the invention of new design means, architectural expression and urban procedures that develop belonging to the city and civic culture.

The criterion of recognizability/identity is relevant for the acceptance of a city square. The space is used adequately when the reconstruction establishes a positive relation of the residents towards the square as the center of local culture 
and when this relation is confirmed after the reconstruction. The confirmation that people feel a sense of belonging to the larger community can be seen in the space of the square, in its utilization, maintenance and participation of residents in local manifestations. In the rest of our text we prefer to use the term recognizability in lieu of the term identity.

2. A NUMBER OF ATTRACTIONS AND DESTINATIONS. Every square possesses multiple subunits, smaller environments attractive for various users. These subunits are segregated by positioning various attractions: a cafe terrace, fountain, sculpture, podium for performances, commercial stands or smaller playgrounds and the like. Attractions allow users to have reason at any point in the day to linger in the square. The principles of adequate planning of the number of attractions and destinations influences the adequacy of use and suitability of the space. In big city squares there should be a greater number of attractions and destinations, such that each offers a different option and possibility for spending time. The application of this principle influences the formation of an adequate program of activities for the use and enjoyment of the space of the city square.

The criterion of diversity expresses the principle of a greater number of attractions and destinations on the square. It expresses the features in the square and features of buildings on to the square, a developed seasonal, permanent and temporary program of activities, a diversity of environments and users who can found in the square. It also includes two more principles that characterize a successful execution of city squares: planned strategies and an active interior and exterior square.

3. AMENITIES. Planning and application of adequate materialization and urban equipment in the square allows for a comfortable use of space. The position, orientation and appearance of benches, position and shape of trash bins, design of the paving, street lighting, fountains or other elements and equipment in the space all influence the recognizability of the place as well as creates the feeling of comfort/enjoyment in dwelling in this space.

Adequate lighting of certain activities, entrances and pathways contributes to the impression of comfort in the evening hours. The performance or presentation of art in public space entertains and encourages gathering and lingering of passers-by.

The criterion of comfort expresses pleasantness, security and enjoyment. If we say that the space of the square or a portion of the square is comfortable for use, it means it will be visited. Frequent use of space and mobile pieces, and its high 
attendance require adequate maintenance, upkeep, repairs and replacement of damaged equipment. In order for the space to be adequately used, it must be adequately maintained, thus the principle of pleasure is expressed through the criterion of comfort.

4. FLEXIBLE DESIGN. An adequate reconstruction of the city square is characterized by the possibility of adapting the space to various uses for residents, the local community and stakeholders. Changes in space are possible if in the course of reconstruction attention was paid to the possibility of flexible design based on existing and future needs. Inadequate analysis of needs can cause inadequate flexibility of the space, and thus a lower level of use and acceptance of the space. An example of flexible design could be a plan for moveable and mountable urban elements and equipment, aiming to diversify the use of space during the day, week, month, year. (Naturally, these additional elements and equipment, such as tables, chairs, benches, umbrellas, awnings etc., have to be provided adequate storage space when not in use.

Using the criterion of flexibility we ensure the acceptance of the square space precisely due to the adaptability of space to new needs and initiatives. The adequacy of use of space is estimated in relation to destinations. The greater the number of destinations, the less the chance of inadequate use of space. If despite a great flexibility of space, there is still inadequate use of the square, the causes should be sought in unresolved problems of the central city zone (e.g. the usurpation of public space by parked cars is the consequence of unresolved issues of parking in the larger square area).

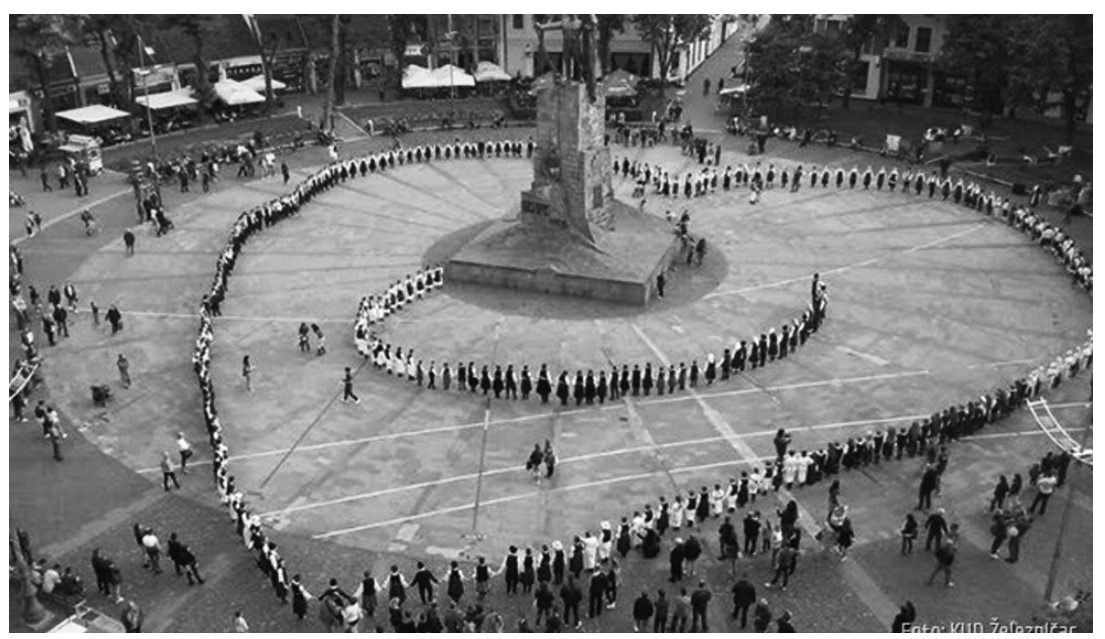

Figure 7. Kraljevo, Festival of children's folklore ensembles. May, 2016 (https://goo.gl/images/vAzHU6) 
5. SEASONAL STRATEGY. The diversity of activities and features positively effects the level of acceptance of the square space. Seasonal strategies refer to the activities and features planned in the square during various season of the year, such as placing an ice rink in the winter, an awning and fountain in the summer months, organization of topical fairs and bazars.

The criterion of diversity expresses a variety of activities and features in the square space, but as mentioned, it also expresses the principles of a greater number of attractions and destinations, as well as an active inner and outer square. These principles are connected, meaning that based on one criterion it is possible to express multiple principles that determine a successful reconstruction of the square space.

6. ACCESS. The principle of adequate access to the space refers to the level of simplicity in approaching the square. The best squares are easily accessible to pedestrians, that is, the streets that lead into it are narrow, crosswalks are clearly marked, the duration of green crossing lights is adapted to pedestrians (not cars), traffic is slowed down, and transport stops are located nearby. If the square is blocked off by a bigger street, it would cut off foot traffic, depriving it of its most basic element: users of space. The access to the space can be seen in another way: adequate planning of the position and number of parking spots strongly influences the access to the space. Further, by careful planning of bike and public transportation lanes/pathways, we increase the level of access to the space and of course its acceptance.

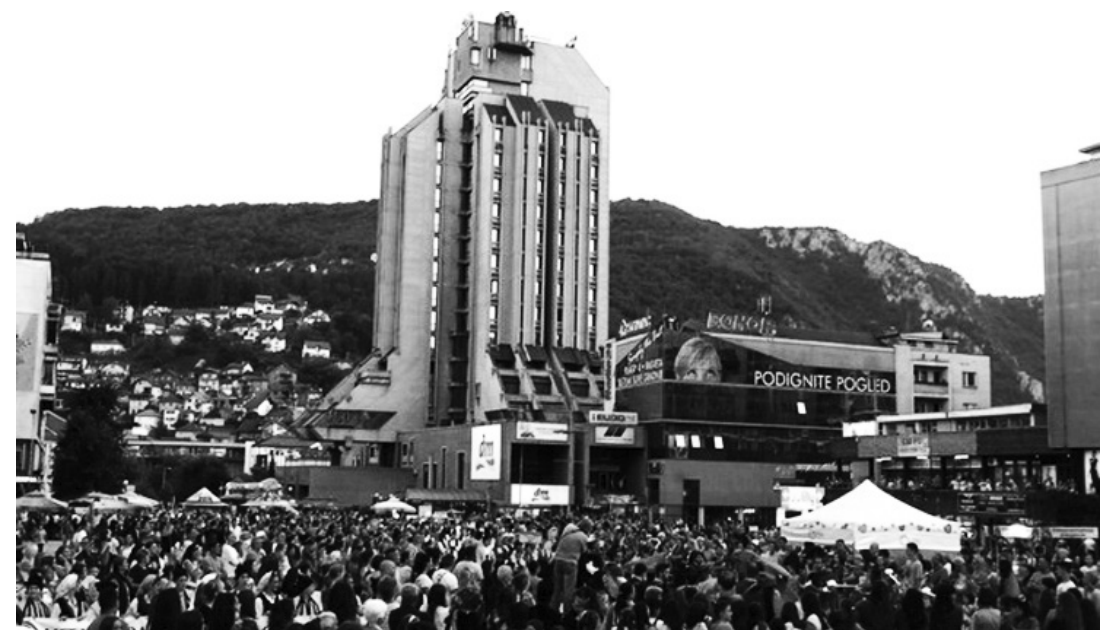

Figure 8. Užice, International Children's Folklore Festival "Licidersko srce”. August, 2016 (https://goo.gl/images/A6mMyK) 
The criterion of accessibility expresses the adequacy of access to the space.

7. INNER AND OUTER SQUARE. Streets make the square reachable. Also impacting its reachability are the surrounding buildings. Attractiveness and diversity of features, above all on the ground floor that form the space of the square, have a large influence on the degree of use of the overall square space. If on the ground floor of the buildings there are active and diverse features, there will be a greater degree of acceptance of the space.

The criterion of diversity expresses the principle of attractiveness and diversity of features and functions of the inner and outer square space.

8. REACHING OUT LIKE AN OCTOPUS. The principle of adequate connectivity of city square space refers to the surrounding urban block, as well as other public spaces throughout the city. The buildings that form the space of the square influence the degree of use of the space, but also the way the square is connected with surrounding streets and blocks influences the degree of accessibility of the space. The atmosphere of the square space transfers to the surrounding streets and blocks. As traffic approaches the square it slows down, strolling becomes more enjoyable, one is able to notice the elements/ monuments in the square, and the features of the buildings in the approaching streets give off the impression of already being on the square space. In this way a portion of the square atmosphere "spills" over onto the surrounding public space and blocks, encouraging mutual connectedness of space.

The principles of access and reaching out are encompassed by the criterion accessibility. An accessible square and buildings approachable from the square influence users of all types to easily arrive at the square or to cross the square in going somewhere nearby. The atmosphere of the square is equally made up by those users who simply cross, those who only peek out of surrounding buildings, those who linger longer or dwell in the square.

9. CENTRAL ROLE OF MANAGEMENT. Adequate management means respecting the needs of permanent and new potential users, which is why the square is ready to adequately "host" anyone. The readiness is the result of adequate management and maintenance of space on the part of the operational body or person in charge of execution of these principles. Adequate management and maintenance of space affects the creation of comfort and security in users. Regular maintenance of the space assures users of the space that order and conflict avoidance in the space is the result of the organization that cares for the space as well as the users. Without adequate management 
and maintenance of the space there can be no ensured adequate access and connectivity, nor can the diversity of functions and features be achieved, nor indeed the recognizability and comfort. Management and maintenance of space does not simply encompass a greater and more diverse number of activities and features or better maintenance, but rather consideration of the overall way of functioning of the space and removal of all conflict and deficiencies, with the advancement of positive ways and examples of use of space.

Thus the principle of adequate management and maintenance of space affects all the criteria used to describe the acceptance of the square space, and also represents the area in which projects of reconstruction of city squares are exposed to risk.

10. DIVERSE FUNDING SOURCES. Planning various sources of financing affects the success of the execution of city square projects. Success in planning, execution and management of square space depends on the ways and sources of financing. If the local government budget cannot ensure the adequate reconstruction financing, it is necessary to ensure sources of funding from private-public partnerships: garnering taxes, short or longterm lease of public space, through sponsorships, etc. Financing strongly affects the adequate reconstruction of city square space and the preservation of quality of space.

Accordingly, the principle of diverse funding sources affects all the criteria used to describe the acceptance of square space, as well as the simultaneous risk to which city reconstruction projects are exposed (the lack of founding).

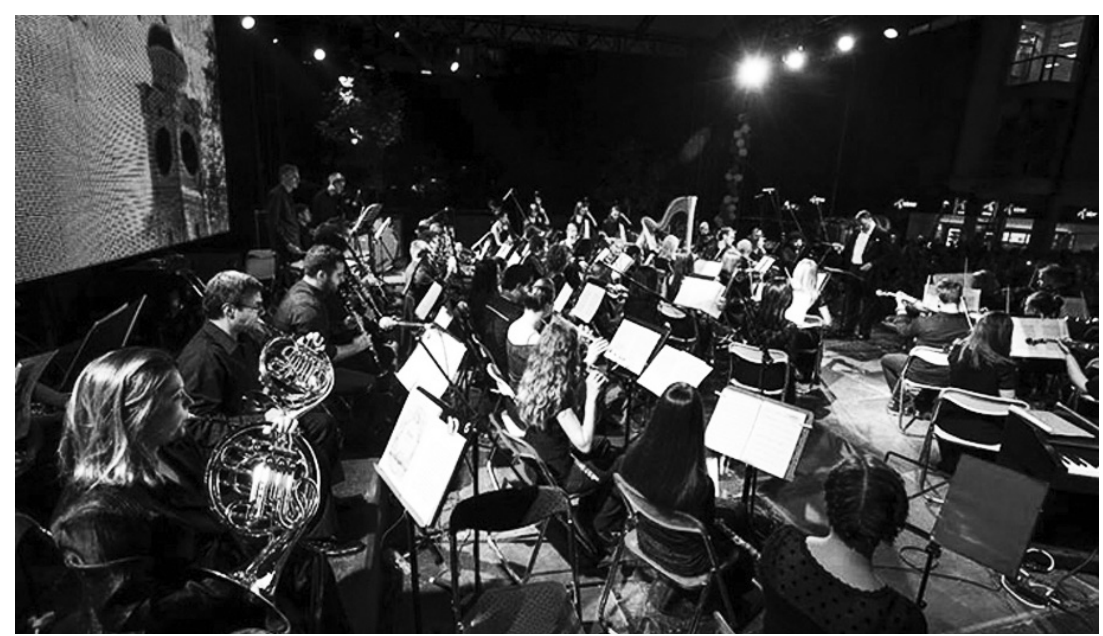


Poor management and maintenance of space is one of the main sources of inadequate use of space (further damage, neglect and destruction), which is why the development of this area when it comes to Serbia should be given proper significance. It is particularly important to mention that here there is another interpretation why Serbian squares have a low level of acceptance: in addition to the given reasons of lack of continuity of civic culture and awareness, we should also consider the insufficiently developed area of management and maintenance of public space, squares in particular.

The results of the study of positions of ten experts in the field of urban design in Serbia, conducted in 2016 using the Delphi Method (by D.P. and M.M.) indicate that city square reconstruction projects in Serbia are highly exposed to risks from the category (area) of management and maintenance of space. The given results show that passive management of activities and features in space, along with poor maintenance of space, permanent and moveable equipment, has a high probability of occurring and strongly affects the acceptance of the square space. The cited risks are directly linked with the capacities and competencies of those employed in the local administration, as well as the quality and type of organization of services and bureaus of the local community. Further, considering the integral process, and not only the project, experts have found:

- that the acceptance of the space of the city square is equally influenced by the risks that occur in the phase of planning, design and construction of the actual city square and by the risks that occur in the phase of use of the space. The phase of space use is often neglected in the execution of the project of reconstruction of the city square and is not included in the overall life cycle of the project. Consideration and identification of the "reconstruction project" with the quality of the technical documentation and execution is a serious oversight in the process of managing a project.

- Risks in the phase of space use are not directly dependent on the risks in the previous phases, but are directly dependent on the quality and way of organizing and management of the space. Adequate execution of the city square reconstruction project must also encompass the influences of the reconstruction on the surrounding. In other words, the adequate management of space spurs "greater acceptance of reconstructed space" on the part of the residents, the local community and stakeholders.

- Ensuring the greatest possible acceptance of the city square space is directly dependent on adequate management of risks that occur in all phases of the project, that is in the entire life cycle of the project, including the phase of use of space 
After looking at the ten criteria for a successful city square with risks to acceptance of the city square in Serbia, we made a selection of five key criteria relevant for the acceptance of the city square: access, flexibility, diversity, recognizability and comfort.

\section{CRITERIA OF ACCEPTABILITY OF THE TOWN SQUARE}

Success of town square reconstruction is confirmed by the residents' use both the actual space of the square and the buildings that frame it (by passing through, lingering, organized, spontaneous, active or passive dwelling in the square). To what extent is the space of the city square used in a way and to the end for which it is projected, and to what extent does it respond to future needs?

What is the measure of acceptance of the square? What criteria ${ }^{32}$ indicate the extent to which the goal of the reconstruction of a square has been met? This portion of the text explains the criteria of access, flexibility, diversity, recognizability and comfort, as the primary criteria of acceptance of the space of city square. We examined the relevance of these criteria and considered whether these five criteria are sufficient for determining the measure of acceptance.

The square as representative public space must be comfortable, accessible and recognizable, since these are the original determinations of the square:

- accessibility confirms belonging to a larger community,

- comfort confirms the greatest concentration of urbanity,

- recognizability confirms that culture of this environment is authentic and lasting.

In case these criteria are not met, then the space of the square is not used to its full format and intention, that is, it is not visited and does not have representative significance. In addition to these three criteria, also relevant are diversity and flexibility, since they respond to the dynamics and plurality of lifestyles in cities. These two criteria are significant for the measure of adequate use of city squares in contemporary conditions: in addition to the original determinations of the square, these criteria show the particularities of the phenomenon of the square today, that is, what the square has ever ensured and what it ought to further ensure. The dynamics of change in the city suggests adaptability of the square to new conditions, while the size of population and respect of differences in use of square space suggests diversity of content and activity. The given criteria correspond to a contemporary context and the needs of future generations, meaning it respects the principle of sustainability. 
How should we define adequate use of a square space? Architectural and urban design of the square applies technical standards and norms to determine the relation of the desirable and possible quality of public space. It is important to say that the standards allow the position regarding the adequate use to be placed in the framework of concrete circumstances. ${ }^{33}$ Thus, for further defining of standards it is necessary to research practices of square reconstruction in Serbia based on the experience of experts familiar with its conditions, procedures and execution, and identify the risks that influence the acceptance of space to which the city square reconstruction projects in Serbia are exposed.

\section{RECOGNIZABILITY - the consistence of a culture}

Whether the square space will be used adequately depends on the square reconstruction and further maintenance establishes, cares and develops a relation to the space as a place in which people feel they belong to the city. Which means:

- in the social sense, the individual in the square feels a belonging to the larger community/civic society

- in the economic sense, that the square is public capital

- in the sense of cultural identity, that it establishes continuity and confirms belonging to a culture that lasts in that given place a significant period of time.

These three levels of belonging to the city are expressed through the use of square space, which is why the occasion of square reconstruction is an opportunity for development of cultural identity. This is a challenge when one considers that cultural identity is the explanation for the low level of acceptance of the square in Serbia.

The square is a place of a high degree of urbanity and a representative public space in which cultural and national identity is expressed. Understood in the broadest sense, culture is the totality of a way of life produced by a group of people, transmitted from generation to generation. ${ }^{34}$ Nikezić points out that in the built environment culture manifests as the basic pattern of any activity connected to creation and existence of the built environment, meaning that the built environment can be understood as the materialization of culture ${ }^{35}$. By constructing public buildings of importance and setting markers in the square space (monuments, fountains, drinking fountains, art installations etc.) we create cultural and building heritage of a city that is unique and enduring. Due to continuous investment in the maintenance and construction of the square, we could say that the square is a window into a culture and that its architectural 
framework allows us to see into contemporary society as well as traces of past times. It is a material trace of values advocated in a given period: who built and ruled the city, which institutions shaped social relations, what events determined history, which people brought advancement to the city and its residents.

The recognizability of a city square is not a characteristic recognized only by the tourist or a traveler, but also citizens who wish to find in this space confirmation that the place in which they live is rich, enduring and unique. For this feeling of pride and belonging, cities with tradition invest into the maintenance and reconstruction of their squares, in order to establish continuity and lasting of civic culture and in order to transfer these forms and values to future generations. In Serbia, the first squares were created after the rule of Turks, with the intention to constitute a national identity and adopt European patterns of construction and city life.

Recognizability can be noticed even on the micro-plan, in the use of local materials, through the crafted details on monuments and the engagement of local craftsmen and persons knowledgeable of local customs, as well as including residents in the choice of local markings, advocated in the paradigm of sustainable development.

Today it is generally accepted that success in the reconstruction of public space depends on how much the citizens themselves have influenced the creation of the solution. Accepting the process of public hearings, participatory workshops and other democratic protocols does not give positive results if the principles of responsibility and accepted solution is abandoned in the execution phase. There are even situations when the populace follows the reconstruction of a square with skepticism or resentment, but upon its completion the square blossoms and is used adequately despite the lack of faith among residents.

What aspects of reconstructed squares indicate oversights in the development of cultural identity? The following characteristics (risks) negatively influence recognizability of a city square, and thus cause a low level of acceptance, that is, inadequate use of the space:

- typical solutions in urban design

- imitating other places

- not using local materials

- not encouraging local production

- not conducting adequate participation of residents

- veering away from the planned solution in the execution

- lack of innovation in setting up the equipment and forming the space (falling into routine) 
- break with continuity (not respecting specificities of previous states and customs of space use)

- lack of cultural features (or their inactive use)

\section{COMFORT - concentration of urban features}

The level of comfort of public city spaces depends on their features, maintenance, readability and materialization of the square space. To comfortably spend time in a square assumes security relative to other people (unknown or unwanted groups), to weather conditions and to the use of surfaces for movement or dwelling.

Jan Gehl's studies show that the activity of others attracts people to spend time in a public space. While some use city space actively, others enjoy the atmosphere and gazing upon ongoing activities. A portion of the square is formed for the purposes of active use - creation of an atmosphere; while a different portion is for the purpose of sitting and watching - enjoying the atmosphere.

A well-equipped square is a space that offers a choice to all users in the portions of the square they seek and in the way they wish to stay on the square. Setting up benches, steps, awnings, pavilions, covered sections, etc. allows greater choice and comfort of spending time in the square. The daily and evening image of the square with the same number, if different, users, testifies to an active space and the turnover of generations of users, that is, that the space is adapted to all age groups.

In a well maintained space, residents recognize care of the relevant city authorities for their comfort in the city space, and conversely, a poorly maintained space causes decay and destruction of equipment and further devastation of public space, proof of mutual mistrust, neglect or poor organization of city services and residents.

The feeling of personal security is stronger in places that are readable, visited, lit, full of features and maintained, where there are no traces of vandalism and where contact with unwanted groups can be avoided. When the space is readable, even if the square is not visited, one gets the impression of being under scrutiny, which negatively influences people's behavior. If the ground floors of buildings face the square (facades partially or entirely transparent) the feeling of security is greater, in particular if shops are lit up at night (whether open or not). 
The feeling of pleasure and security with regard to weather is achieved with protective elements (shelter, covered objects). The quality of the surface affects the feeling of security in movement and crossing the square. The quality of the surface depends on the leveling of the square (there is no uncontrollable holding of water in the square, the slope of ramps, height of steps and pavement edges), as well as of the choice of material of adequate texture (no reflection, slipping, etc.), how bearing and rigid it is (without broken tiles at moment of installation and exploitation).

In reconstructed squares, what points to oversights in ensuring comfort? Solutions that lead to inadequate use of the square, that is, insufficient presence of people in the square due to a feeling of insecurity and lack of comfort of space are:

- inactive ground floors

- dark and unreadable portions of the square

- light pollution (overly lit portions of the square)

- noise, inadequate sound distribution

- lack of covered areas

- visual barriers

- poor choice of material and poor leveling (uneven and slippery surfaces, water holding in the square)

- high pavement edges, subtle small irregularities in the leveling, physical barriers

- insufficient equipment (light, trash management etc.)

- poor maintenance (lack of upkeep of existing or damaged equipment)

\section{DIVERSITY}

Urbanity, the main characteristic of the development of a city, requires a concentration of diverse activities/features, mostly of the secondary and tertiary economic sector, as well as the presence of urban way of life. Diversity of features that frame the square and the numerous ways of using the square surface by various groups (simultaneously or at given times) indicate a high degree of urbanity of a living environment.

The presence of people in the square depends on the activities taking place. Therefore, the attendance in the square depends most on its function. The greatest attendance of a market square is on market day, a protest square at a time of a political or social event, a social square at holiday time. How is the square used the rest of the time? Following the content that make the space 
active, in whose absence life in the square recedes, there is a smaller number of visitors, which leaves the impression of an abandoned and uncontrolled space. Such conditions attract unwanted groups, vandalism, devastation of space, great cost of repair and maintenance and finally, low level of acceptance of the square.

For an adequate use of the square space, it is important to organize the necessary number of features in the buildings that surround the square and orient them towards the square, while the surface of the square should be oriented such that it can hold various activities readable from the positions meant for sitting or passive dwelling in the square.

Diversity of features assumes a broad spectrum of content that suits the needs and interests of various groups of users. Users differ according to age, lifestyle, standard, physical ability (and limitation), which is reflected in their differing requirements in spatial organization. In democratic societies, their right to the use of public space is equal, which today the criterion of diversity raises into the rank of primary criterion for the evaluation of acceptance of a square.

In Serbian cities, the problem of separation of the square area from the surrounding built structures can also be seen in the financing of the reconstruction of the square. Financing the reconstruction, under the auspices of the public sector, encompasses the square area only; while the facades and the general state of the surrounding buildings are not taken into consideration, nor is there any encouragement of investment from stakeholders. One should keep in mind that the original role of squares in Serbia was evaluating real estate (ranking of zones in relation to the distance from the city square). The convenience of location is reflected in the economic benefit of the owner of the lot/building and is returned to the city through taxation. Sources of financing the maintenance and reconstruction of the square should be combined and based on the taxation of those who take advantage of an active square, taxation of fairs and similar commercial activities, tourist visits, sponsorships and public-private partnerships.

If the reconstruction allows the realization of a program that would activate the square throughout the whole year, then such an organization should be provided with adequate financing or else establish a program based on sustainable funding. That is to say that it is not enough to ensure financing of the reconstruction alone, but rather it is necessary to develop mechanism of financing of maintenance and execution of planned activities. 
Oversights made in reconstruction are mostly regarding poor estimation of cost of program execution, favoritism of a group of users or a formal fulfilling of individual needs without their harmonization. Diversity does not only refer to the amount, but the harmonization of any number of features. In part, spatial organization can reconcile diverse groups of users, while the overall success of a solution requires an adequate program and system of use of space and tolerance of differences.

- poorly adapted space for all users

- exclusivity (prices of services favor users with a higher standard of living)

- unestablished system of use

- space for certain activities is not properly bordered (made too small or too large)

- additional features are not active in the evening hours

- there is no executive body in charge of organizing activities

- there is no official service in charge for managing and maintaining the space

4. FLEXIBILITY - adaptability to conditions, needs, technologies

The space of the square is used for gathering various categories of users. The execution of quotidian and occasional activities requires good spatial organization. It is crucial to distribute and proportion the subunits well. The size of the space depends on the number of users and types of activities. Depending on the type of event (political rallies, concerts, performances) the entire surface of the square is occupied; temporary markets (flower, honey festivals, etc.) only take up a portion of the square, while the rest is still used for regular activities. For a simultaneous realization of various regular/quotidian features on the square space, it is desirable to form subunits of adequately portioned and equipped. Flexibility of spatial organization with new needs turns an unpredictable situation into an opportunity for a positive change.

Flexibility of space is a relevant criterion, as much for the assessment of success, as for acceptance of the city square. Inadequate use of the square space is a consequence of the spatial solution for the envisaged, but obsolete function, where the design is not adaptable to new demands, standards of equipment or technologies of maintenance, climactic changes, or else it does not ensure the possibility of simultaneous events taking place. All of this is reflected in the attendance of the square, leaving inactive space to be used for solving acute, most often traffic, problems. 
What do we encounter in the square space in Serbian cities that negatively influences the flexibility of space.

- fenced off subunits (fences around church yards)

- square areas overgrown by plants

- large unevenness in the leveling

- stationary equipment that reduces readability

- segregation of portions of the square

- lack of moveable equipment and space for its storage

- insufficient space for unplanned activities

- partial execution of projects

\section{ACCESS - belonging to the city}

Access to the square is a characteristic that positively influences the presence of people and is the precondition for its dynamic use. The concentration of features around the square (on the square itself and in the surrounding area) encourages and is reflected in a certain frequency of people, while the spatial organization of entering and crossing the square makes it a destination or an important place of transit. ${ }^{36}$ Since frequented places attract other people to watch and enjoy the atmosphere itself, the square also gathers those who passively dwell in it, becoming part of the overall lively image. The opportunity that everyone has to linger in the square to the extent and how they wish, to be seen and see others, to simply cross or else run into someone is the main attribute of the square, which is why access to the square is just one of the criteria that needs fulfilling in forming, reconstructing or transforming it.

Seen on the level of the micro-plan (only the surface of the square with the buildings that frame it), access requires easy approach to any place in the square and any building. Thus the analysis looks at various types of movement (pedestrian, bike, vehicular and other) and adapts the leveling design of the square and the choice of material for paving to the needs and limitations of the users and the orientation of the buildings to the square. The needs of the users depend on their physical abilities, meaning that the pavement surface need to be carefully made for the movement of children, elderly and persons with disabilities. Their needs also depend on their interests, requiring the surfaces (and portions of the square) to be adaptable for various forms of leisure activities in the public space.

Accessibility to features depends on the way in which the approach to the object is organized, that is, the way in which a building is integrated with the square. It is not enough, although it is important, that the main entrance into the 
building be oriented toward the square. It is important to design pre-space, a transition zone between the building and the inner square, a zone that integrates these features. As an illustration, there could be terraces as the expansion of the feature of the building (exposure of features to the interior of the square), or there could be a colonnade that separates the ground floor of a building from the square in order to provide the feeling of shelter (withdrawing from the square).

What adversely affects access? What kinds of states in reconstructed squares indicate oversight in ensuring access? We site several situations that can today be seen in squares in Serbia, so that future reconstruction of these squares could avoid these oversights:

- Extremely unleveled surface, further exacerbated by sudden high steps, discourages the movement of those with lowered abilities or mobility (such as parents with strollers, people in wheelchairs, older persons, small children, etc.)

- The building entrance orientation is not on the square side, so people in that building remain outside the square, even though they would otherwise take part in the square activities

- Entrance to a building is on the side of the square, but with certain elements, i.e. barriers creates the impression that it is not desirable to approach the building (high pavement edges, flower beds that narrow the path, pillars that prevent vehicular and pedestrian movement)

- The entrance is not adequately indicated, is too subtle, too invisible or its access is not evident

- The facade on the ground level does not have visual contact with the square, nor is it visible from the square what is the feature the building has to offer

- Fulfilling the conditions of access to building "piecemeal" rather than in overall design, that is, without considering the whole. As an illustration, we offer the case when each entrance individually, in its own way, set up a ramp, despite the fact that there could have been a single ramp with a platform for two or more entrances

- The access to a building and its entrance are insufficiently lit, leaving both the building and the space in front to appear inaccessible.

\section{CONCLUSION NOTE}

The historic town matrix with the square in its middle is a cultural heritage of our cities that testifies to a period of building a national identity and adoption of a European model of urbanism and civic culture. The reconstructions of historic 
town squares are undertaken in either a planned way or ad hoc for the needs of political campaigns without a longterm plan of maintenance or developed mechanisms of sustainable management of public space. Although we have experts for methodology of participational and collaborative methods of planning, the implementation of these approaches on the local level only begins with international projects. Adequate forms of timely participation give positive results in the process of development of strategy of integral urban development of central city zones. The given strategies provide for the reconstruction of public spaces in accordance with sustainable principles, in particular developing intersectional topics: accessibility, participation of citizens, and living environment and sustainability. We believe that the precondition of sustainable reconstruction as a portion of the network of public spaces is the understanding of the question of acceptance, which is adequate use of the town square. Cultural identity and lack of continuity of the urban culture is an insufficient explanation for the low level of acceptance of the town square.

Ensuring the greatest possible acceptance of the historic town square is directly tied to the adequate management of the risks that occur in all phases of the project, that is, in the course of the overall life cycle of the project, which includes the phase of space use. Upon comparing the ten criteria for a successful town square with the risks to acceptance of the historic square in Serbia, we suggest five key criteria relevant for its improvement and acceptance: accessibility, flexibility, diversity, recognizability and comfort. By following the satisfaction of these criteria and which risks (causes) in which phase and area of activity (planning, execution, use and maintenance) can impact the adequate use of the reconstructed square - we initiate the process of risk management in the execution of the reconstruction of historic town squares.

NOTES

1

2
Бранко Максимовић, Урбанизам у Србији (Београд: Издавачка књижара Косте Ј. Михаиловића, 1938).

European Commission. Accessed February, 20, 2016, http://ec.europa.eu/culture/policy/culturepolicies/cultural-heritage_en.htm

Branka Šekarić, "Očuvanje istorijskih gradova u 21. veku" (Preservation of Historic Towns in the 21 st century) In Procedings of Second International Conference Preservation and Impuvement of Historic Towns, 61-82. (Sremski Karlovci: Pokrajinski zavod za zaštitu spomenika kulture Petrovaradin i Opština Sremski Karlovci, 2015), 61-82.

UNCSD. "The Future We Want” Accessed February, 20, 2016, http://www.un.org/disabilities/ documents/rio20_outcome_document_complete.pdf

Ibid.

Leipzig Charter on Sustainable European Cities 2007. Agreed on the occasion of the Informal Ministerial Meeting on Urban Developmant and Territorial Cohesion, EU German Presidency. Leipzig, 2007.

See Harald Muller et al. Strengthening of Local Land Management in Serbia. (Belgrade: AMBERO Consulting Representative Office, 2016) 
Nenad Nerić et al., The Integrated Urban Development Strategy for the Inner City of Kraljevo Kraljevo 2030 (Kraljevo: Direkcija za urbanizam Kraljevo, 2015), 61.

Danica Radojičić et al., The Integrated Urban Development Strategy for the Inner City of Užice Užice 2030 (Užice: Narodna biblioteka Užice, 2014), 67.

Original plan see: Maksimović, 1938, p.108

Nenad Nerić et al., The Integrated Urban Development Strategy for the Inner City of Kraljevo Kraljevo 2030. (Kraljevo: Direkcija za urbanizam Kraljevo, 2015), 86.

Old town core is listed cultural properti of great value from 1970. See: Spomeničko nasleđe Srbije (Beograd: Republićki zavod za zaštitu spomenika kulture Srbije, 1998), p. 70.

Dragan Jevtović et al., The Integrated Urban Development Strategy for the Inner City of Kragujevac - Kragujevac 2030 (Kragujevac: Urban Planning Directorate Kragujevac, 2013), 50.

European Commission, Towards and integrated approach to cultural heritage for Europe Accessed February, 20, 2016, http://ec.europa.eu/culture/policy/culture-policies/cultural-heritage_en.htm Open Method of Cooperation (OMC)

Available at http://ec.europa.eu/culture/policy/strategic-framework/european-coop_en.htm See http://www.unesco.org/new/en/brasilia/culture/cul-ture-and-development/culture-insustainable-development/

Maksimović, 108,113.

Споменичко наслеђе Србије (Cultural Monuments of Serbia), (Београд: Републички завод за заштиту споменика културе Србије, 1998), 70.

European Commission, Towards and integrated approach to cultural heritage for Europe Accessed February, 20, 2016, http://ec.europa.eu/culture/policy/culture-policies/cultural-heritage_en.htm

See Ratka Čolić "Integrated Urban Development Strategy as an Instrument for Supporting Urban Governance", Serbian Architectural Journal, VII, 3, (2015): 317-342

Vladan Djokić, Urban typology: City Square in Serbia. (Beograd: Univerzitet u Beogradu, Arhitektonski fakultet, 2009)

Vladimir Macura, Čaršija i gradski centar, Razvoj središta varoši i grada Srbije XIX i prve polovine XX veka. (Niš: IRO Gradina, 1984), 153-154.

Nikola Dobrović, "Obnova i izgradnja Beograda - Konture budućeg grada”. Beograd između stvarnosti i sna, izbor tekstova, Urbanizam Beograda 66-67, (1982): 180-192.

For further explanations see: Vladan Djokić, Urbana morfologija: Grad i gradski trg (Beograd: Univerzitet u Beogradu, Arhitektonski fakultet, 2004), 267-275

Stephen Wheeler. "Planning sustainable and livable cities." In The city reader, edited by R. T. LeGates \& F. Stout, (London: Routledge, 1998), 486-496.

Hildebrand Frey, Design the City. Toward a more sustainable urban form. (London and New York: Spon Press, 2005), 4.

Sternberg, Ernest. "An Integrative Theory of Urban Design" Journal of the American Planning Association 66, 3 (2000): 265-278.

Jan Gehl, Cities for People. (Washington, Covelo, London: Island Press, 2010)

Ibid.

Available at http://www.pps.org/reference/squaresprinciples/

Criterion (Greek: krinein = to distinguish, judge) is a means or measure intended for judging or comparing that contains a series of characteristics or conditions, qualitative or quantitative designations. For our purposes, the criterion is the characteristic of a thing that is the measure of its value for the assessment of its quality. Zoran Nikezić, Građena sredina i arhitektura. (Beograd: Univerzitet u Beogradu, Arhitektonski fakultet, 2007)

Zoran Nikezić, Građena sredina i arhitektura. (Beograd: Univerzitet u Beogradu, Arhitektonski fakultet, 2007), 64 .

Ibid.,7

Ibid.

It is characteristic for squares in Serbia to be formed along streets, as their expansion or in a place where two or more streets merge. See Vladan Djokić, Urban Typology: City Square in Serbia. (Belgrade: University of Belgrade, Faculty of Architecture, 2007). 
Čolić, Ratka. "Integrated Urban Development Strategy as an Instrument for Supporting Urban Governance.” Serbian Architectural Journal VII, 3 (2015): 317-342

Dobrović, Nikola. "Obnova i izgradnja Beograda - Konture budućeg grada.” Beograd između stvarnosti i sna, izbor tekstova, Urbanizam Beograda 66-67 (1982): 180-192.

Djokić, Vladan. Urban Typology: City Square in Serbia. Belgrade: University of Belgrade, Faculty of Architecture, 2007.

Djokić, Vladan. Urbana morfologija: Grad i gradski trg. Beograd: Univerzitet u Beogradu, Arhitektonski fakultet, 2004.

Erlewein, Shina. "Sustainable Development and Intangible Cultural Heritage into Development" In Perceptions of Sustainability in Heritage Studies, edited by Marie-Theres Albert, 71-84. Berlin, Boston: Gruyter, Walter de GmbH, 2015.

European Commission. Accessed February, 20, 2016, http://ec.europa.eu/culture/policy/culturepolicies/cultural-heritage_en.htm

Frey, Hildebrand. Design the City. Toward a more sustainable urban form. London and New York: Spon Press, 2005.

Gehl, Jan. Cities for People. Washington, Covelo, London: Island Press, 2010.

Hoeven, FD van der, and Rosemann, HJ. Urban transformations and sustainability. Progress of research issues in Urbanism 2005. Delft: IOS Press, 2006.

Jevtović, Dragan, Ratka Čolić and Ina Zerche. The Integrated Urban Development Strategy for the Inner City of Kragujevac - Kragujevac 2030, Kragijevac: Urban Planning Directorate Kragujevac, 2013.

Macura, Vladimir. Čaršija i gradski centar, Razvoj središta varoši i grada Srbije XIX i prve polovine XX veka. Niš: IRO Gradina, 1984.

Максимовић, Бранко. Урбанизам у Србији. Београд: Издавачка књижара Косте J. Михаиловића, 1938.

Muller, Harald, Babette Wehrmann, Ratka Čolić, Ariana Furst, Branko Begović, Christoph Jochheim-Wirtz, Branko Božić, Miodrag Ferenček and Slavka Zeković. Strengthening of Local Land Management in Serbia. Belgrade: AMBERO Consulting Representative Office, 2016.

Nerić, Nenad, Ratka Čolić, Jochen Gauly, Michael Engel and Jens Gerhardt. The Integrated Urban Development Strategy for the Inner City of Kraljevo - Kraljevo 2030. Kraljevo: Direkcija za urbanizam Kraljevo, 2015.

Nikezić, Zoran. Građena sredina i arhitektura. Beograd: Univerzitet u Beogradu, Arhitektonski fakultet, 2007.

Project for Public Spaces. "10 Principles for Successfull Squares.” Accessed February, 15, 2016, http://www.pps.org/reference/squaresprinciples

Radojičić Danica, Ratka Čolić and Ina Zerche. The Integrated Urban Development Strategy for the Inner City of Užice - Užice 2030, Užice: Narodna biblioteka Užice, 2014.

Sternberg, Ernest. "An Integrative Theory of Urban Design.” Journal of the American Planning Association 66, 3 (2000): 265-278.

Šekarić, Branka. "Očuvanje istorijskih gradova u 21. veku" (Preservation of Historic Towns in the 21 st century) In Procedings of Second International Conference Preservation and Impuvement of Historic Towns, 61-82. Sremski Karlovci: Pokrajinski zavod za zaštitu spomenika kulture Petrovaradin i Opština Sremski Karlovci, 2015.

UNCSD. “The Future We Want” Accessed February, 20, 2016, http://www.un.org/disabilities/ documents/rio20_outcome_document_complete.pdf

UNESCO. "The Role of Culture in Sustainable Development.” Accessed February, 20, 2016, http://www.unesco.org/new/en/brasilia/culture/culture-and-development/culture-in-sustainabledevelopment/ 
UN-HABITAT. "Global Public Space Toolkit - From Global Principles to Local Policies and Practice.” Accessed February, 15, 2016, http://unhabitat.org/wp-content/uploads/2015/10/ Global\%20Public\%20Space\%20Toolkit.pdf

Wheeler, Stephen. "Planning sustainable and livable cities." In The city reader, edited by R. T. LeGates \& F. Stout, 486-496. London: Routledge, 1998. 